\title{
Indonesian Journal of Educational
}

Research and Technology

Journal homepage: http://ejournal.upi.edu/index.php/IJERT/

\section{Teaching and Learning with Technology: Effectiveness of ICT Integration in Schools}

\author{
Swarali Sanjay Shah* \\ Department of Management Studies, Rajarambapu Institute of Technology, India \\ ${ }^{*}$ Correspondence: E-mail: swarushah1229@gmail.com
}

\section{A B S T R A C T S}

Integration of Information, Communication, and Technology (ICT) will assist teachers to the global requirement to replace traditional teaching methods with technology-based teaching and learning tools and facilities. In Malaysia, ICT is considered as one of the main elements in transforming the country to future development. The Ministry of Education, through the latest Education Blueprint (2013-2025), insights the importance of technology-based teaching and learning into the schools' national curriculum. This study aims to analyze teachers' perceptions of the effectiveness of ICT integration to support the teaching and learning process in the classroom. A survey questionnaire was distributed randomly to a total of 101 teachers from 10 public secondary schools in Kuala Lumpur, Malaysia. The data for this quantitative research were analyzed for both descriptive and inferential statistics using SPSS (version 21) software. The results indicate that ICT integration has great effectiveness for both teachers and students. Findings indicate that teachers' well-equipped preparation with ICT tools and facilities is one of the main factors in the success of technology-based teaching and learning. It was also found that professional development training programs for teachers also played a key role in enhancing students' quality learning. For future studies, there is a need for consideration of other aspects of ICT integration especially from a management point of view concerning strategic planning and policymaking.

\author{
ARTICLEINFO \\ Article History: \\ Submitted/Received 29 Dec 2021 \\ First revised 19 Jan 2022 \\ Accepted 21 Jan 2022 \\ First available online 23 Jan 2022 \\ Publication date $01 \mathrm{Sep} 2022$ \\ Keyword: \\ ICT integration, \\ Malaysia, \\ Teaching and learning, \\ Technology effectiveness, \\ Education.
}




\section{INTRODUCTION}

In this 21st century, the term "technology" is an important issue in many fields (Puspitawati et al., 2021; Baldwin, 2009; Liu \& Gee, 2017), including education. This is because technology has become the knowledge transfer highway in most countries. Technology integration nowadays has gone through innovations and transformed our societies that have totally changed the way people think, work and live (Ghavifekr \& Rosdy, 2015).

As part of this, schools and other educational institutions which are supposed to prepare students to live in "a knowledge society" need to consider Information, Communication, and Technology (ICT) integration in their curriculum. Integration of ICT in education refers to the use of computer-based communication (Rachmawati, 2019). Specifically, it incorporates into daily classroom instructional process. In conjunction with preparing students for the current digital era, teachers are seen as the key players in using ICT in their daily classrooms (Ghavifekr et al., 2014). This is due to the capability of ICT in providing a dynamic and proactive teachinglearning environment, while ICT integration aims to improve and increase the quality, accessibility, and cost-efficiency of the delivery of instruction to students, it also refers to benefits from networking the learning communities to face the challenges of current globalization (Albirini, 2006; Abdullah et al., 2017).

The process of adoption of ICT is not a single step, but it is an ongoing and continuous step that fully supports teaching and learning and information resources. ICT integration in education generally means technology-based teaching and learning process that closely relates to the utilization of learning technologies in schools (Ghavifekr \& Rosdy, 2015; Wang, 2008; Sarker et al., 2019). Because students are familiar with technology and they will learn better within the technology-based environment, the issue of ICT integration in schools, specifically in the classroom is vital. This is because the use of technology in education contributes a lot in the pedagogical aspects in which the application of ICT will lead to effective learning with the help and supports from ICT elements and components. It is right to say that almost all ranges of subjects' starting from mathematics, science, languages, arts, and humanistic and other major fields can be learned more effectively through technologybased tools and equipment.

ICT can be used in various ways where it helps both teachers and students to learn about their respective subject areas. Technology-based teaching and learning offer various interesting ways which include educational videos, stimulation, storage of data, the usage of databases, mind-mapping, guided discovery, brainstorming, music, World Wide Web (www) that will make the learning process more fulfilling and meaningful (Ghavifekr \& Rosdy, 2015).

On the other hand, students will benefit from ICT integration where they are not bounded to the limited curriculum and resources, instead, hands-on activities in a technology-based course are designed to help them stimulate their understanding of the subject. It also helps teachers to design their lesson plans in an effective, creative and interesting approach that would result in students' active learning.

Previous research proved that the use of ICT in teaching will enhance the learning process and maximize the students' abilities in active learning. Identified three main stages for ICT to be highly valued and regarded by the teachers; integration, enhancement, and complementary.

The integration approach is about implementing the right use of ICT in particular subject areas that involved complex concepts and skills to improve students' achievement and attainment. Besides, the review of the curriculum is also needed so that only related ICT resources and appropriate software will be installed for the main aims and objectives of the

DOI: http://dx.doi.org/10. 17509/xxxx.xxxx p- ISSN 2775-8419 e- ISSN 2775-8427 
curriculum to be achieved. The enhancement approach is about using ICT to give great emphasis on the topic introduced. For instance, Microsoft PowerPoint can be used to present the topic in a very innovative and creative way that will lead to discussion and exchanging ideas and thoughts (Ghavifekr \& Rosdy, 2015).

Finally, a complementary approach is when the ICT is used to aid and support the student's learning (Arukaroon \& Krairit, 2017). This approach allows students to be more organized and efficient in which they can take obtain notes from the computer, submit their works by email from home as long as they meet the deadline, and look for information from various sources provided online to fulfill the task given to them.

\section{METHODS}

\subsection{Research Design}

In this research, a quantitative methodology was used to collect and analyze the data obtained from all the respondents. The researchers developed the questionnaire and finalized it before being distributed to the targeted group of respondents. Few sections on the questionnaire were designed specifically to address research Knowledge on Technology Use Confirmation and Actual Use Intension to use Perceived ease of use Perceived usefulness objectives regarding the effectiveness of ICT integration for students in learning and effective elements of ICT integration in a public school in Kuala Lumpur, Malaysia. Therefore, the questionnaire was distributed to obtain the data from the respondents.

\subsection{Population and Sampling}

The overall total of respondents for this research was 101 teachers from public primary and secondary schools in Kuala Lumpur, Malaysia. The questionnaire was randomly distributed to the respondents with teaching backgrounds regardless of gender, race, teaching experience as well as highest teaching experience. There are no preferences set by the researchers as long as the respondents come with teaching backgrounds especially in public primary and secondary schools in Kuala Lumpur, Malaysia. Since the targeted respondents for this research are meant for individuals with teaching backgrounds, the researchers tried to get especially teachers from public primary and secondary schools in Kuala Lumpur to be part of this research. Hence, the questionnaires distributed are not equal in numbers where teachers from secondary schools dominate the overall population as compared to teachers from primary schools.

\subsection{Instrument}

A survey questionnaire with a total of 43 items was used as the main instrument in this study to analyze the effectiveness of ICT integration in teaching and learning in public schools in Kuala Lumpur, Malaysia. A total of 101 questionnaires were distributed where all respondents were asked to read the statements given and choose their answers based on the 4-Likert scale: 4= Strongly Disagree, 3= Disagree, 2= Agree, and 1= Strongly Agree. The questionnaires consisted of 4 sections. Section $A$ is about the demographic background of the respondents consists of 8 items that include gender, race, teaching experience, type of school, school area, preference of teaching style, highest academic qualification, and the ability to handle ICT in teaching. The other 3 sections in the questionnaire focus more on teachers' perception and the elements of effectiveness of ICT integration in schools. Section B comes with 15 items that look into teachers' perception of ICT in teaching, section C consists of 10 
items that look into the effectiveness of ICT integration for students in learning meanwhile section D comes with 10 items that look into the effective elements of ICT integration in teaching.

\subsection{Data Collection Procedure}

The researchers modified the questionnaire before it is being finalized and distributed to the target group of respondents. Then, each researcher takes up 50 and 51 questionnaires respectively made a total of 101 questionnaires being distributed to all respondents. The data were collected within 2 weeks through random distribution and some of the questionnaires were sent to respondents' email. The respondents were given 3-5 days to complete the questionnaire and send it back to the researcher for data analysis. After 2 weeks, all the complete filled-up questionnaires were gathered and collected for further data analysis by the researcher to get the output and findings for the research.

\subsection{Data Analysis Process}

All the data collected from the respondents were gathered together to be analyzed using Statistical Package for the Social Sciences (SPSS) version 21. The analysis includes both descriptive and inferential analysis. The researchers used descriptive analysis to analyze the frequency and percentage of the overall population in the demographic background. Besides, it is also used to determine the mean, standard deviation, frequency, and percentage to identify the effectiveness of ICT integration for students in learning as well as the effective elements of ICT integration in teaching in public schools in Kuala Lumpur.

\section{RESULTS AND DISCUSSION}

The findings of this research will give the output needed to answer the research questions. The findings are done according to the sections in the questionnaire and some inferential analysis that includes reliability testing and Mann-Whitney $U$ testing is also conducted towards the overall data (see Table 1).

The results of this study show that technology-based teaching and learning is more effective in comparison to the traditional classroom (Sumitra et al., 2021). This is because using ICT tools and equipment will prepare an active learning environment that is more interesting and effective for both teachers and students. Moreover, this study proved that students learn more effectively with the use of ICT as lesson designs are more engaging and interesting (Hashim et al., 2020).

Accordingly, the participants agreed that integrating ICT can foster students' learning. The Internet Use in EFL Teaching and Learning in Northwest China and the findings indicated that teachers have a positive attitude regarding the use of the Internet in teaching and learning; teachers have some knowledge about Internet use in teaching and learning; they have not well-integrated Internet into teaching and learning so far; teachers' knowledge about ICT and network technology is very limited.

Likewise, the first two points were similar to the findings of this research, in which most teachers think ICT integration for students in learning is effective. Because students can develop the confidence to have better communication and the ability to express their thoughts and ideas; ICT helps students to be more creative and imaginative as their knowledge paradigm expend, and ICT helps students to possess all four skills in learning when

DOI: http://dx.doi.org/10. 17509/xxxx.Xxxx p- ISSN 2775-8419 e- ISSN 2775-8427 
they can acquire necessary information and knowledge (Saripudin et al., 2020). However, this study finds that public school teachers in Kuala Lumpur, Malaysia are not given enough time to learn and be comfortable with ICT.

Table 1. The demographic background of respondents.

\begin{tabular}{|c|c|c|}
\hline Factors & Frequency & Percentage \\
\hline \multicolumn{3}{|l|}{ Gender } \\
\hline Female & 82 & 81.19 \\
\hline Male & 19 & 18.81 \\
\hline \multicolumn{3}{|l|}{ Race } \\
\hline Malaysia & 36 & 35.64 \\
\hline India & 22 & 21.78 \\
\hline Chinese & 39 & 38.61 \\
\hline Others & 4 & 3.96 \\
\hline \multicolumn{3}{|l|}{ Teaching experience } \\
\hline$<1$ year & 20 & 19.8 \\
\hline $1-5$ years & 36 & 35.64 \\
\hline $6-10$ years & 35 & 33.66 \\
\hline$>10$ years & 11 & 10.89 \\
\hline \multicolumn{3}{|l|}{ Type of school } \\
\hline Primary & 37 & 36.63 \\
\hline Secondary & 64 & 63.37 \\
\hline \multicolumn{3}{|l|}{ School Area } \\
\hline Urban & 79 & 78.22 \\
\hline Rural & 22 & 21.78 \\
\hline \multicolumn{3}{|l|}{ Preference of teaching style } \\
\hline Conventional/Traditional & 42 & 41.58 \\
\hline Modern/Contemporary (Use of ICT) & 59 & 58.42 \\
\hline \multicolumn{3}{|l|}{ Highest academic qualification } \\
\hline Diploma & 10 & 9.90 \\
\hline Degree & 63 & 62.38 \\
\hline KPLI & 19 & 18.81 \\
\hline Master & 9 & 8.91 \\
\hline \multicolumn{3}{|l|}{ The ability to handle ICT in teaching } \\
\hline High & 25 & 24.75 \\
\hline Medium & 67 & 66.34 \\
\hline Low & 9 & 8.91 \\
\hline
\end{tabular}

This study found that most teachers think ICT integration is effective, but ICT tools provided in school are not enough nor in good condition; training and professional development are not adequately provided for teachers; technical supports are somehow provided but can be improved from time to time; and not a very good condition of computer lab in school with well-functioning tools and facilities (Karniawati et al., 2021).

In conclusion, the very first stage of ICT implementation must be effective to make sure that, teachers and students can make the best use of it. Thus, preparations for technologybased teaching and learning begin with proper implementation and supports by the school's top management (Rochmawati \& Rahmayanti, 2021). If the implementation process of technology integration in schools takes place appropriately from the very beginning stage and continuous maintenance is adequately provided, ICT integration in schools will result in huge success and benefits for both teachers and students (Riyanto et al., 2021). 
The use of ICT especially in teaching and learning is more about practicality as compared to theories and that is why teachers must be given time to learn and explore it, face the "trialand-error" phase before they are completely comfortable with its usage and able to make use of it for teaching and learning. Finally, the integration of ICT in the classroom needs serious consideration to increasing the competency of the country's education system. This will help in increasing the world ranking of the national education and produce a better future workforce. To enhance the use of ICT in the classroom, the government needs to improve and change the teachers' beliefs about the integration of ICT in the classroom. As the teachers' role is the key role in making any of the new policies be implemented efficiently and successfully.

The changes that are taking place are driven by advanced technology and communication devices that should be available to students wherever they are either at school or home. In addition, the need for teachers to be literate and have good skills and knowledge in using ICT to improve their teaching methods and approach is desired to promote effective learning as well as to meet the demand of the 21st century teaching skills.

It might be too common for issues and challenges of ICT integration to be discussed but an in-depth study of ICT integration in core subjects in schools is least discussed. It is good if further studies can be made based on what barriers teachers are facing in using ICT in their daily classrooms in schools. Besides, rather than just focusing on public schools, it is best if this study can be conducted in 3 major schools, we have in Malaysia including public schools, Chinese schools as well as Indian schools. This is because some schools might have more funding that makes ICT implementation much faster and easier. It is good if a comparison can be made between different schools in which it can take the good side as examples and make improvements needed from the flaws identified. Other than that, it is highly recommended for comparison studies about ICT integration in teaching and learning to be done between public and private schools. This is because most private schools permit students to bring gadgets to school and the teaching and learning process takes place within the use of ICT. It would be exciting to see the findings of the effectiveness of ICT integration in public and private schools.

\section{CONCLUSION}

This study informs an integration of ICT to assist teachers to the global requirement to replace traditional teaching methods with technology-based teaching and learning tools and facilities. This study analyses teachers' perceptions of the effectiveness of ICT integration to support the teaching and learning process in the classroom. The results indicate that ICT integration has great effectiveness for both teachers and students. Findings indicate that teachers' well-equipped preparation with ICT tools and facilities is one of the main factors in the success of technology-based teaching and learning. Professional development training programs for teachers also played a key role in enhancing students' quality learning. For future studies, there is a need for consideration of other aspects of ICT integration especially from a management point of view concerning strategic planning and policymaking.

\section{AUTHORS' NOTE}

The authors declare that there is no conflict of interest regarding the publication of this article. Authors confirmed that the paper was free of plagiarism. 


\section{REFERENCES}

Abdullah, M. S., Toycan, M., and Anwar, K. (2017). The cost readiness of implementing elearning. Custos E Agronegocio On Line, 13(2), 156-175.

Albirini, A. (2006). Teachers' attitudes toward information and communication technologies: The case of Syrian EFL teachers. Computers and Education, 47(4), 373-398.

Arukaroon, B., and Krairit, D. (2017). Impact of ICT usage in primary-school students' learning in The Case of Thailand. International Journal of Web-Based Learning and Teaching Technologies (IJWLTT), 12(2), 21-42.

Baldwin, R. G. (2009). The climate for undergraduate teaching and learning in STEM fields. New Directions for Teaching and learning, 2009(117), 9-17.

Ghavifekr, S., and Rosdy, W. A. W. (2015). Teaching and learning with technology: Effectiveness of ICT integration in schools. International Journal of Research in Education and Science, 1(2), 175-191.

Ghavifekr, S., Razak, A. Z. A., Ghani, M. F. A., Ran, N. Y., Meixi, Y., and Tengyue, Z. (2014). ICT integration in education: Incorporation for teaching and learning improvement. Malaysian Online Journal of Educational Technology, 2(2), 24-45.

Hashim, S., Masek, A., Abdullah, N. S., Paimin, A. N., and Muda, W. H. N. W. (2020). Students' intention to share information via social media: A case study of COVID-19 pandemic. Indonesian Journal of Science and Technology, 5(2), 236-245.

Karniawati, N., Simamora, R., and Zain, B. T. (2021). Information Communication and Technology for Political Communication Ethics. International Journal of Computer in Law and Political Science, 1, 21-26.

Liu, L. G., and Gee, H. (2017). Determining whether commercial publishers overcharge libraries for scholarly journals in the fields of science, technology, and medicine, with a semilogarithmic econometric model. The Library Quarterly, 87(2), 150-172.

Puspitawati, L., Nurhasanah, A., and Khaerunnisa, A. (2021). Utilization of Communication Technology for Business. International Journal of Informatics, Information System and Computer Engineering (INJIISCOM), 2(1), 47-54.

Rachmawati, R. (2019). Utilization and Quality of Information System for Administration Services Based on ICT In Patehan, Kraton, Yogyakarta. Indonesian Journal of Science and Technology, 4(1), 55-63.

Riyanto, Y., Nandiyanto, A. B. D., and Muhammad, N. (2021). The effectiveness of distance teaching and learning activities in primary schools. Indonesian Journal of Multidiciplinary Research, 1(1), 1-6.

Saripudin, S., Rohendi, D., and Abdullah, A. G. (2020). Developing information technology in opencourseware: From movements to opportunities in Asia. Indonesian Journal of Science and Technology, 5(3), 308-320.

Sarker, M. N. I., Wu, M., Cao, Q., Alam, G. M., and Li, D. (2019). Leveraging digital technology for better learning and education: A systematic literature review. International Journal of Information and Education Technology, 9(7), 453-461. 
Shah. Teaching and Learning with Technology: Effectiveness of ICT Integration in Schools | 140

Sumitra, I. D., Wirawan, E., Putra, M., Kusumaningrat, I., and Maulana, H. (2021). Design of webinar information system for people with hearing impairments. Indonesian Journal of Community and Special Needs Education, 1(2), 77-86.

Wang, Q. (2008). A generic model for guiding the integration of ICT into teaching and learning. Innovations in education and teaching international, 45(4), 411-419. 